\title{
Analysis of a Portuguese HEI teachers \\ experience in the context of COVID-19
}

Análise da experiência de professores do ensino superior

português no contexto da COVID-19

\section{Elisabete Brito (D) ${ }^{* 1}$, Natália Gomes (D) ${ }^{\dagger 2}$, Pedro Tadeu (D) ${ }^{\ddagger 1}$ and Carlos Brigas (iD $\S 1$}

\author{
${ }^{1}$ Instituto Politécnico da Guarda, Escola Superior de Educação, Comunicação e Desporto - \\ Unidade de Investigação para o Desenvolvimento do Interior, CI\&DEI - Centro de Estudos em \\ Educação e Inovação, Guarda, Portugal. \\ ${ }^{2}$ Instituto Politécnico da Guarda, Escola Superior de Tecnologia e Gestão - Unidade de \\ Investigação para o Desenvolvimento do Interior, CI\&DEI - Centro de Estudos em Educação e \\ Inovação, Guarda, Portugal.
}

\begin{abstract}
The current context of the pandemic crisis has led to unexpected educational changes. It has forced the institutions to rapidly adapt their teaching and learning methodologies in all areas, especially in higher education. This atypical situation, has given rise to numerous reflections on the ability of institutions to adapt to this new paradigm. This research aims to understand how the Portuguese Higher Education Institution (Polytechnic of Guarda) teachers have adjusted their teaching and learning process to distance learning. We constructed a quantitative investigation with a survey applied to the population, consisting of 158 individuals, achieving 102 valid answers, $65 \%$ of the population. The results show that despite the initial doubts and concerns at the beginning of the process, there was always a substantial increase in work volume. There was a rapid adaptation to new teaching and learning methodologies in COVID-19 time. Overall, most of the inquiries considered this distance learning experience to be very positive.
\end{abstract}

Keywords: Teaching and learning methodologies. Higher education. Distance learning. Collaborative tools.

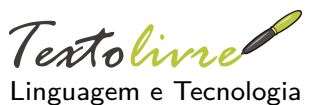

DOI: $10.35699 / 1983-$

3652.2021 .33579

Session:

Dossier

Corresponding author:

Elisabete Brito

Edited by:

Anna Izabella M. Pereira

Received on:

December 11, 2020

Accepted on:

February 28, 2021

Published on:

June 22, 2021

This work is licensed under a "CC BY 4.0" license.

(c) (i)

\section{Resumo}

O contexto atual da crise pandémica levou a mudanças educacionais inesperadas. Obrigou as instituições a adaptar rapidamente as suas metodologias de ensino e aprendizagem em todas as áreas, especialmente no ensino superior. Esta situação, atípica, deu origem a inúmeras reflexões sobre a capacidade das instituições de se adaptarem a este novo paradigma. Esta pesquisa tem como objetivo entender como os professores de uma Instituição de Ensino Superior (Instituto Politécnico da Guarda) ajustaram o seu processo de ensino e aprendizagem à situação de ensino a distância. Foi construída uma investigação quantitativa com um levantamento aplicado à população, sendo esta composta por 158 elementos, alcançando 102 respostas válidas, $65 \%$ da população. Os resultados mostram que, apesar das dúvidas e preocupações no início do processo, significando sempre um aumento substancial no volume de trabalho, houve uma rápida adaptação às novas metodologias de ensino e aprendizagem neste período de COVID-19. No geral, a maioria dos inquiridos considerou esta experiência de ensino a distância muito positiva.

Palavras-chave: Metodologias de ensino e aprendizagem. Ensino superior. Ensino a distância; ferramentas colaborativas.

\section{Introduction}

In the current globalized knowledge society of constant scientific, technical innovation and technology, higher education institutions (HEls) should consider distance learning ( $E @ D$ - Ensino a distância) as a fundamental factor in its strategic management policy. The HEl should reflect on its form of integration to empower students with essential competencies for the 21st century (RODRIGUES,

\footnotetext{
*Email: beta@ipg.pt

†Email: ngomes@ipg.pt

‡mail: ptadeu@ipg.pt

§Email: brigas@ipg.pt
} 
2015). Thus, the use of technologies should be thought of to make the teaching-learning process more efficient and effective, aiming that learning happens and is meaningful (KONRATH; TAROUCO; BEHAR, 2009).

The Portuguese HEls have shown concerns about incorporating new teaching methods compared to traditional methodology (face-to-face teaching). This happens through the implementation of several processes. Among these, we could state the following: Learning Management Systems (LMS) platforms; the creation of Massive Open Online Course (MOOC) courses; the design of courses in blended learning mode (b-learning) and by mobile learning (m-learning). These social learning or learning models are characterized by the ubiquity of collaborative systems and tools (OLIVEIRA; LIMA; PORTO, 2015).

Several studies show the advantages associated with this type of education, which enables all those involved (educational institutions, students and teachers) to obtain different benefits that contribute to supporting and increasing the effectiveness and success of educational systems (ALSABAWY; CATER-STEEL; SOAR, 2016; MATTAR; LOUREIRO; RODRIGUES, 2020).

During the Covid-19 pandemic, the $E Q D$ emerged as the obligatory and necessary alternative to meet the pressing needs of a primarily unprepared educational community, but which quickly had to adapt to this reality in spaces and times different from face-to-face reality.

\section{Contextualization}

For public health reasons, in the COVID-19 pandemic, the world and the country stopped, schools closed. According to a study published in the spring of 2020, more than 1.2 billion children have had their classroom teaching activity suspended, altering teaching methods and developing and trying to adapt to $E @ D$ in record time. This reality also extended to higher education, which, in Portugal, was until then mostly face-to-face. This had to be rethought and draw in new ways, had to reinvent itself to give immediate answers to a reality that needs a time of mise en place to respond to the demands of quality teaching.

The same study asks whether, effectively, after the pandemic, this education system will remain and ultimately be part of the educational strategy of all countries. It is essential to mention that before COVID-19, there was already, on the part of educational institutions, considerable growth in the introduction and use of digital technologies, with an investment in ECD expected to exceed $\$ 350$ billion in 2025 (LI; LALANI, 2020). However, it should be noted that the implementation of this teaching-learning system has many socio-economic constraints, particularly in underdeveloped countries, due to the lack of an effective information society.

Thus, it is essential to reflect on the innovations that study on E@D present, as well as on the methodologies and good practices of teachers, which allow making this teaching an effective learning environment and a competitive advantage for institutions (MCGILL; KLOBAS; RENZI, 2014; ÍLIN et al., 2017).

\section{Skills and role of the teacher in the ECD}

The process of $E Q D$ is not as simple as is sometimes stated, often denoting great ignorance and even some counter-information concerning this practice. It is not difficult to hear, wrongly, in some media and social networks that the process to take place is needed only by a teacher and the use of any technology. The growing diversity of platforms, the lack of knowledge of their use in creative, innovative and methodologically student-centred approaches, the absence or scarcity of digital skills on the part of teachers and students, the lack of strategies about the $E \subseteq D$ modality hinders not only the process but also its increasing use with quality, in institutions.

In the construction of online learning communities, increasingly present, one of the most critical aspects is student-centred learning, based on the premise that knowledge and relationships between participants are developing through the established interactions (MARTINHO, 2014). In this line of thinking, knowledge about students is obtained and deepened in the same proportion that the collaborative learning process is developed and improved (ANDERSON, 2008; GARRISON; VAUGHAN, 2008; PALLOF; PRATT, 2007), to make students' teaching and learn more effectively, and the teacher's 
figure and understanding of his multiple roles in cyberculture times are fundamental: trainer, director of teaching materials, researcher, mediator and advisor (BRUNO; LEMGRUBER, 2010).

Zwaneveld and Bastiaens (2007) argue that most ICT competencies for teachers are four: Individual media-competencies; critical media-competencies; lifelong learning competence; and Supervising learning process. Teachers must assume a multidimensional role and are urged to integrate a range of different and numerous competencies. According to Wake, Dysthe, and Mjelstad (2007), using ICT and new approaches to teaching and learning boost the foundation of two new areas of action: academic as a mentor and as an orchestrator.

The process of distance learning, as regards teaching, necessarily consider that the design, development, and assessment of virtual education introduce features and require specific teaching tasks (MAJOR, 2010; SPECTOR, 2007).

The role of the teacher is reinforced in $E @ D$ environments since it requires more excellent monitoring, the use of motivation techniques and the use of more proactive methodologies. The teacher should thus be a facilitator of the process, promoting the use of virtual environments, collaborative tools and teaching processes directed to techniques and new methodologies (DUNLAP; GRABINGER, 2008; AMIT, 2015), of which can be examples of the following ones:

- flipped learning;

- problem-based learning;

- gamification learning;

- creation of individual work plans;

- management of synchronous and asynchronous classes;

- making or reusing explanatory videos;

- conducting collaborative activities;

- diversification of resources and tools;

- ensuring more effective communication and feedback.

In this context, and due to the importance to understand advantages, disadvantages and potential and successful methodologies, this study aimed to systematically analyze the implementation level for e-learning $(E @ D)$ in higher education system education from the Guarda Polytechnic Institute (IPG) in Portugal, during the COVID-19 pandemic.

\section{Methods}

The survey's target group consisted of professors teaching on the four schools of IPG in the city of Guarda and Seia, Portugal: School of Education, Communication and Sport; School of Technology and Management; School of Tourism and Hospitality Management and the School of Health Sciences. An item-based questionnaire was constructed based on a literature search. The items were grouped into the following three main areas:

- General information about the demographic profile of the participants;

- Information about expectative, methodologies and platforms used in E@D;

- Information about personal measurement data working on ECD.

The initial questionnaire was validated through a peer review approach online according to the pre-test method during the spring semester 2019/20. Peer reviewers $(n=4)$ were professors expert on e-learning education and ICT use within education environments. The returned comments were collected, and the questionnaire adapted accordingly to the suggestions made.

The final questionnaire for this study contained 27 items and was delivered to all professors teaching in the four schools. Access to the questionnaire was provided by an invitation email link supplied by Google Forms. The survey started in June 2020 and the data collection ended in September 2020. The analysis was undertaken using the SPSS 23 program.

\section{Results}

In this section, we present the results obtained with the questionnaire. The first table (Table 1 ) shows a characterization of the population of this study.

There is an evident division regarding gender among professors (52,5\% male and $47,5 \%$ female), 
Table 1. Sociodemographic characterization

\begin{tabular}{|c|c|c|c|}
\hline & Variables & $\mathrm{N}$ & $\%$ \\
\hline \multirow{3}{*}{ Gender } & Male & 53 & $52,5 \%$ \\
\hline & Female & 48 & $47,5 \%$ \\
\hline & Total & 101 & $100 \%$ \\
\hline \multirow{6}{*}{ Age (years) } & Up to 45 years & 24 & $23,8 \%$ \\
\hline & From 46 to 50 years & 9 & $18,8 \%$ \\
\hline & From 51 to 55 years & 39 & $38,6 \%$ \\
\hline & More than 55 years & 19 & $18,8 \%$ \\
\hline & Total & 101 & 100 \\
\hline & Minimum $=34 ;$ Maximum $=64 ;$ Mean $=$ & .53 & rd deviation $=6.52$ \\
\hline \multirow{5}{*}{$\begin{array}{l}\text { Educational } \\
\text { qualifications }\end{array}$} & Degree & 4 & $4,0 \%$ \\
\hline & Master & 17 & $16,8 \%$ \\
\hline & $\mathrm{PhD}$ & 69 & $68,3 \%$ \\
\hline & Expert & 11 & $10,9 \%$ \\
\hline & Total & 101 & $100 \%$ \\
\hline \multirow{5}{*}{ School in IPG } & $\begin{array}{l}\text { Superior School of Education, Com- } \\
\text { munication and Sport } \\
\text { ESECD }\end{array}$ & 30 & $29,7 \%$ \\
\hline & $\begin{array}{l}\text { Superior School of Technology and } \\
\text { Management } \\
\text { ESTG }\end{array}$ & 49 & $48,5 \%$ \\
\hline & $\begin{array}{l}\text { Superior School of Health Sciences } \\
\text { ESS }\end{array}$ & 13 & $12,9 \%$ \\
\hline & $\begin{array}{l}\text { School of Tourism and Hospitality } \\
\text { Management } \\
\text { ESTH }\end{array}$ & 9 & $8,9 \%$ \\
\hline & Total & 101 & $100 \%$ \\
\hline
\end{tabular}

Source: own elaboration. 
regarding the age groups, the group between 51 and 55 years (38,6\%) overlap the other groups. The same happens with the qualifications; the group of persons that have $\mathrm{PhD}$. is very significate in the institution $(68,3 \%)$. Schools are divided following a proportional dimension, with the most significant number of professors in ESTG (48,5\%) and the smallest in ESTH $(8,9 \%)$.

The following table (Table 2) shows the experience of taught and trained in the E@D system.

Table 2. Experience $E @ D$

\begin{tabular}{llll}
\hline & Yes & 40 & $39,6 \%$ \\
Throughout his career taught in E@D & No & 61 & $60,4 \%$ \\
& Total & 101 & $100 \%$ \\
\hline \multirow{3}{*}{ Have you ever trained in E@D } & Yes & 45 & $44,6 \%$ \\
& No & 56 & $55,4 \%$ \\
& Total & 101 & $100 \%$ \\
\hline
\end{tabular}

Source: own elaboration.

Professors who have taught, or have trained in $E @ D$, are less than those who never had this type of experience, showing that most professors don't have experience in both situations.

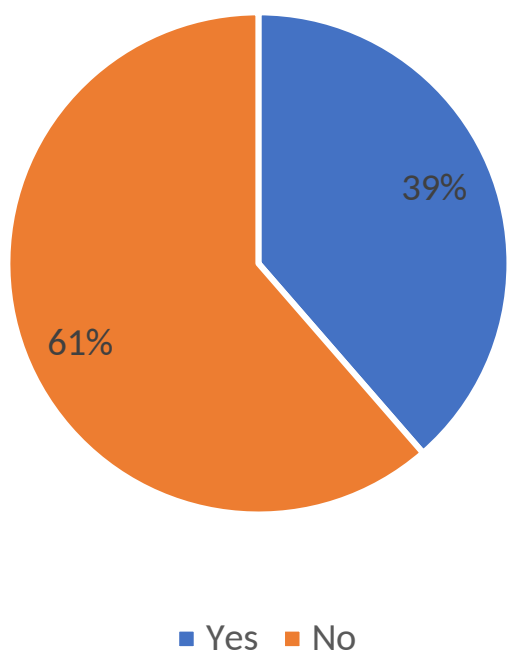

Figure 1. ICT equipment bought

Source: own elaboration.

There was an evident improvement of conditions at home to achieve the goal of E@D classes, and we have $61 \%$ of the professors that have brought new computer, or similar equipment, to deal with the process, as we see in Graph 1.

Regarding the process, and before starting, most of the professors are very concerned with the process of $E @ D(58,42 \%)$, as we see in Graph 2.

The following table (Table 3) gives some details regarding the essential options to achieve the objectives in the different syllabus of the institution degrees.

In the last question, the respondents can choose a maximum of three option among the different suggestions. The main options choose, Develop new methodologies that promote a more active role of students (17,3\%) and Establish new approaches during the presentations/online classes (17,3\%). On the other hand, the options that were not chosen so often were Make videos explaining the story $(3,7 \%)$ and Define new bibliography and/or complementary information on the Internet (4,0\%).

The following table (Table 4) defines the perspective of professors before starting the process concerning the traditional education process versus the new $E @ D$ using a Likert scale (1- Totally disagree; 2- Disagree; 3- Neither agree nor disagree; 4- I agree; 5- Totally Agree).

The previous table (Table 4) indicates that the professors choose I've spent more time planning and preparing classes most of the times with an average of 4,62 and a median of 5 , giving a clear 


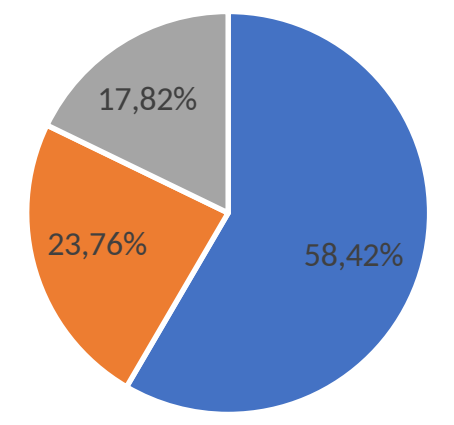

- Concerned $\quad$ Satisfied $\square$ Excited

Figure 2. Feeling at the beginning of the process about E@D

Source: own elaboration.

Table 3. Experience $E @ D$

\begin{tabular}{|c|c|c|c|}
\hline & \multicolumn{2}{|r|}{ Answers } & \multirow{2}{*}{$\%$ (total respondents) } \\
\hline & $\mathrm{N}$ & $\%$ (total responses) & \\
\hline $\begin{array}{l}\text { Learn how the video conferencing platform } \\
\text { would work }\end{array}$ & 49 & $16,3 \%$ & $48,5 \%$ \\
\hline $\begin{array}{l}\text { Develop new methodologies that promote a } \\
\text { more active role of students }\end{array}$ & 52 & $17,3 \%$ & $51,5 \%$ \\
\hline Change curriculum planning & 28 & $9,3 \%$ & $27,7 \%$ \\
\hline Change evaluation methods & 41 & $13,6 \%$ & $40,6 \%$ \\
\hline $\begin{array}{l}\text { Establish new approaches during the presen- } \\
\text { tations/online classes }\end{array}$ & 52 & $17,3 \%$ & $51,5 \%$ \\
\hline Define new practical exercises & 40 & $13,3 \%$ & $39,6 \%$ \\
\hline $\begin{array}{l}\text { Define new bibliography and/or complemen- } \\
\text { tary information on the Internet }\end{array}$ & 12 & $4,0 \%$ & $11,9 \%$ \\
\hline $\begin{array}{l}\text { Search for information so that students } \\
\text { can complement their study through the } \\
\text { Flipped Learning methodology }\end{array}$ & 16 & $5,3 \%$ & $15,8 \%$ \\
\hline Make videos explaining the story & 11 & $3,7 \%$ & $10,9 \%$ \\
\hline Total & 301 & $100,0 \%$ & \\
\hline
\end{tabular}

Source: own elaboration. 
Table 4. Characteristics of the teacher's perspective regarding traditional education versus $E @ D$ in pandemic

\begin{tabular}{llll}
\hline Items & Average & $\begin{array}{c}\text { Standard } \\
\text { deviation }\end{array}$ & Median \\
& & 0,85 & 4,00 \\
\hline $\begin{array}{l}\text { I easily adapted to this new methodology } \\
\text { Easily adapted to the use of new platforms and collaborative } \\
\text { tools }\end{array}$ & 4,18 & 0,78 & 4,00 \\
I've spent more time planning and preparing classes & 4,62 & 0,63 & 5,00 \\
$\begin{array}{l}\text { I developed teaching methodologies that promoted the active } \\
\text { role of students in the search for new learning }\end{array}$ & 4,04 & 0,81 & 4,00 \\
$\begin{array}{l}\text { Promoting the development of the competencies areas of the } \\
\text { students' profile }\end{array}$ & 3,91 & 0,83 & 4,00 \\
$\begin{array}{l}\text { I reformed the way I taught classes } \\
\text { I've been adhering to the teaching materials }\end{array}$ & 4,24 & 0,68 & 4,00 \\
$\begin{array}{l}\text { I've set the evaluation parameters } \\
\text { I have changed the teaching and learning process to promote } \\
\text { the greater autonomy of students }\end{array}$ & 4,24 & 0,74 & 4,00 \\
$\begin{array}{l}\text { I have changed the teaching and learning process to be more } \\
\text { dynamic and interactive }\end{array}$ & 4,05 & 0,96 & 4,00 \\
$\begin{array}{l}\text { I have changed the teaching and learning process so that } \\
\text { most classes can take place asynchronously }\end{array}$ & 2,47 & 0,86 & 4,00 \\
$\begin{array}{l}\text { I encouraged the establishment of regular communications } \\
\text { I've deferred more time to clarify doubts }\end{array}$ & 4,37 & 0,74 & 4,00 \\
\hline
\end{tabular}

Source: own elaboration.

Note: Cronbach's Alpha $=0.786$

signal that most of them agree with this statement. Contrary to the answer, I have the teaching and learning process so that most classes can take place asynchronously, that collect a mean of 2,47 and a median of 2. A large number of professors was not choosing the asynchronous process is preferable.

The following graph (3) compares the professor expectations before and after the process.

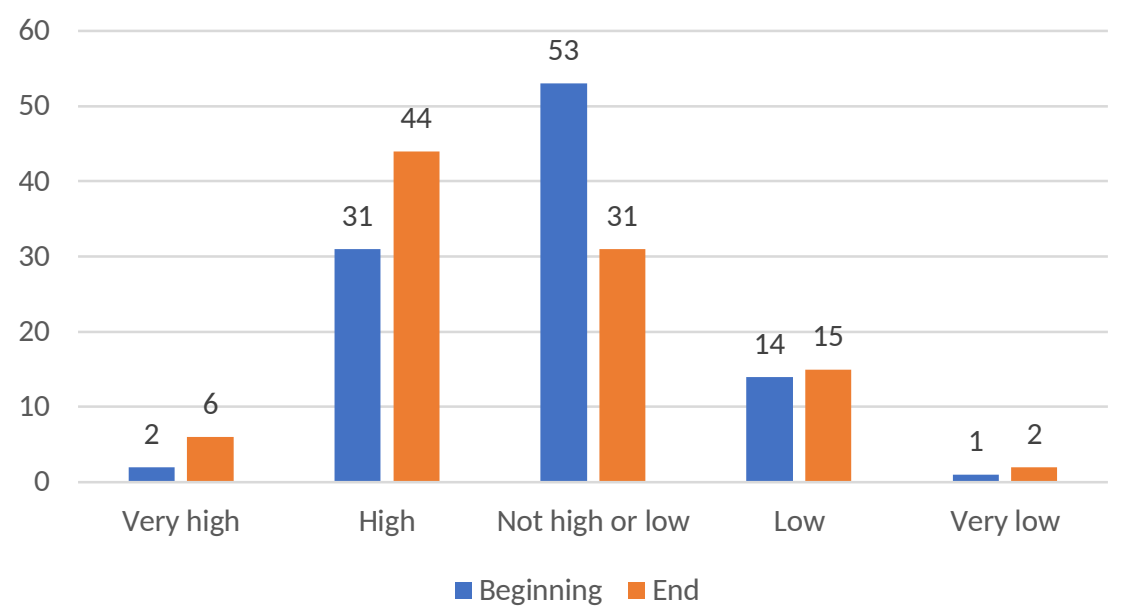

Figure 3. Teacher expectation level (before and after)

Source: own elaboration.

From the graphic, we observe that the professors who have low and very low expectations at the beginning maintained this opinion. The professors that didn't have either low or high expectations (not high or low) have changed their opinion after going through the process by raising the very high and the high values of the answers.

The following graphic (4) show the results of the professor's expectations regarding the students.

There was an evident increase of the very satisfied and satisfied options when comparing the beginning and end of the process expectations regarding the students in the professors' point of view.

The following graphic (5) shows professors' perception regarding the necessary competencies that 


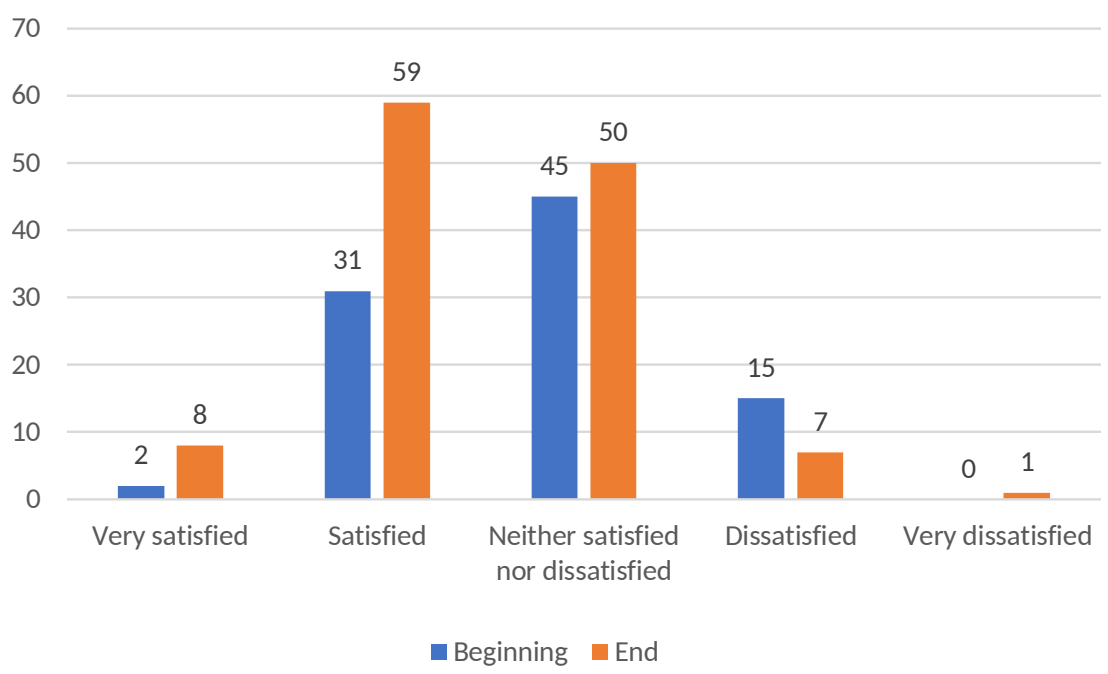

Figure 4. Teacher perception of student satisfaction (before and after)

Source: own elaboration.

students have to develop a good autonomous work in the $E @ D$ on the use of tools.

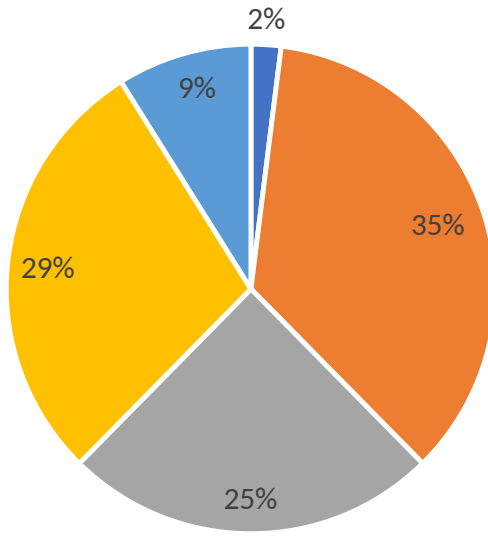

- Totaly agree $\quad$ Agree $\quad$ Neither agree nor disagree $\quad$ Disagree $\quad$ - Totaly disagree

Figure 5. Does the majority of students have the skills to develop an autonomous, responsible and critically study in $E @ D$ ?

Source: own elaboration.

There isn't a clear vision from the answers giving by the professors; 38\% disagree and totally disagree, while $37 \%$ agree and totally agree. This opposite vision could be explained by the different types of degrees and syllabus existing inside the institution.

Graph 6 shows the number of daily hours of work in front of a computer.

Almost $48 \%$ of the professors spend between 6 hours and 8 hours per day, and a significant number, $35 \%$, spend more than 8 hours in front of a computer. This includes the regular synchronous classes and all the necessary preparation.

The following figure (7) shows the desire of the professors regarding the methodology that could be applied in the next year.

Most professors prefer a mixed process from the analyses, a b-learning methodology (52\%), while a small number $(10 \%)$ prefer the pure $E @ D$. It's interesting to notice that the process used for so long, the face-to-face, only enters in the preferences of $38 \%$ of the professors.

\section{Conclusions}

In the context of the COVID-19 pandemic, the world and the country stopped, schools closed, due to the Covid-19 pandemic, the E@D emerged as the obligatory and necessary alternative to meet the 


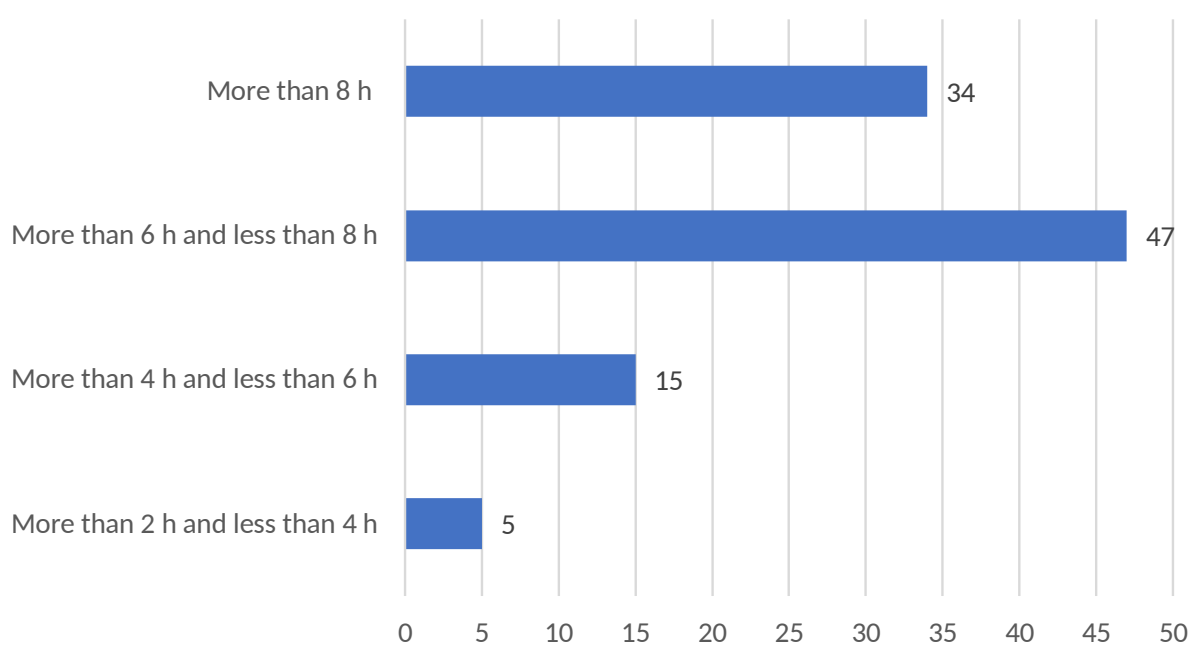

Figure 6. Number of hours daily working in front of the computer Source: own elaboration.

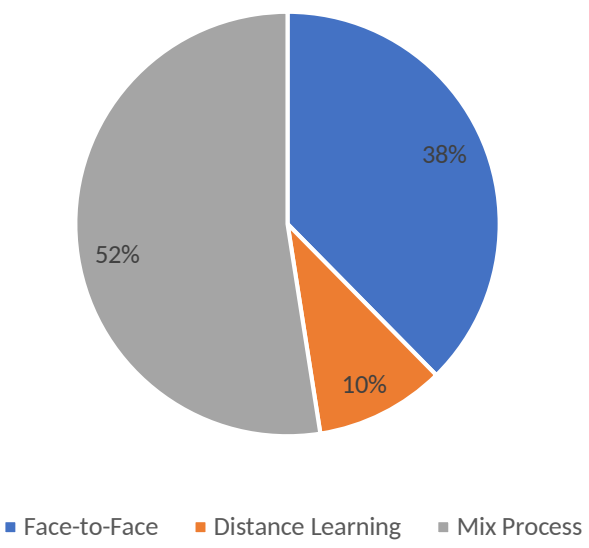

Figure 7. What teaching methodology would you choose for 2020/2021.

Source: own elaboration.

pressing needs of a primarily unprepared educational community, but which quickly had to adapt to this reality, in spaces and times different from face-to-face reality.

Students, teachers and all the intervenient in environment education altering teaching methods and trying to adapt methodologies, materials and IT tools to ECD.

The present study has the intention to draw the situation regarding de methodologies and digitally enhanced learning and teaching practice at the HEI Polytechnic of Guarda in Portugal.

With this study, we obtained results that allow us to understand how the teachers of a Higher Education Institution (Polytechnic of Guarda) have adapted their teaching-learning process to the situation of distance learning, their expectations.

The survey's target group consisted of all professors teaching at the four schools of IPG in Guarda and Seia, Portugal (School of Education, Communication and Sport; School of Technology and Management; School of Tourism and Hospitality Management and the School of Health Sciences).

The results obtained with the questionnaire underline the following aspects:

- The number of professors who have taught, or have trained in E@D, is less than those who never had this type of experience in teaching or training. This shows that most of the professors don't have experience in both situations.

- Most teachers purchased equipment that would allow them to carry out all the tasks planned during the classes.

- The study also made it possible to verify that most teachers were not confident in adhering to the distance learning methodology. 
- To achieving the objectives, teachers develop new methodologies that promote a more active role of students and establish new approaches during the presentations/online classes. This demonstrated that teachers spent more time preparing the lessons and materials.

- Teachers preferred to perform synchronous tasks instead of asynchronous tasks.

- Regarding the necessary competencies that students have, develop good autonomous work in the $\mathrm{E} @ \mathrm{D}$ on tools. In this case, isn't a clear vision from the answers giving by the professors

- When professors are asked about the methodology that could be applied in the following year, the results show us that most prefer a mixed process, b-learning methods, while a small number prefer the pure $E @ D$. Another interesting fact is that the approach being used for so long, face-to-face, only enter in the preferences of $38 \%$ of the professors.

The results obtained through the application of surveys show a great capacity of teachers to adapt to this new reality despite the initial doubts and concerns at the beginning of the process. Other relevant aspects are the investment in the acquisition of hardware, the increase in work resulting from the need for more time for the preparation of classes, the adaptation of didactic materials, and reformulating the way they were taught. On the other hand, there was a quick adaptation to new teaching and learning methodologies, most of which considered this distance learning experience very positive.

Nevertheless, we can mention that despite this fast adaptability, teachers continue to prefer synchronous activities. In their perspective, in future situations, the use of b-learning models should be privileged.

Like it was stated in the Gaebel et al. (2021),

Months of unvoluntary remote learning and teaching have brought a clear demonstration that all that is technically possible is not socially desirable. These, rather than questions of technology and more or less online or blended learning, are the issues that will have to drive the discussions on the transformation of higher education.

So each institution must make a deep analysis of its structure, conditions, human resources, and the students. Studies like these could help the HEl achieve better results and adapt to new realities, either because we are inside the XXI century (the old future) or because pandemic situations turn upside down the old fashioned contexts that tend to appear more often.

\section{Acknowledge}

This work is funded by National Funds through the FCT - Foundation for Science and Technology, I.P., within the scope of the project Refa UIDB/05507/2020. Furthermore we would like to thank the Centre for Studies in Education and Innovation (CI\&DEI) and the Polytechnic of Guarda for their support.

\section{References}

ALSABAWY, Ahmed Younis; CATER-STEEL, Aileen; SOAR, Jeffrey. Determinants of perceived usefulness of e-learning systems. Computers in Human Behavior, v. 64, p. 843-858, Nov. 2016. DOI:

10.1016/j.chb.2016.07.065. Available from:

<https://linkinghub.elsevier.com/retrieve/pii/S0747563216305556>. Visited on: 1 June 2021.

AMIT, G. Choosing the right e-learning methods: factors and elements. E-learning Industry, v. 24, 2015.

Available from: <https://elearningindustry.com/choosing-right-elearning-methods-factors-elements $>$.

Visited on: 1 June 2021.

ANDERSON, Terry (Ed.). The theory and practice of online learning. 2nd ed. Edmonton: AU Press, 2008.

BRUNO, Adriana Rocha; LEMGRUBER, Márcio Silveira. Docência na Educação online: professorar e (ou) tutorar? In: BRUNO, A. R.; BORGES, E. M.; SILVA, L. S. P. (Eds.). Tem professor na rede. Juiz de Fora: Editora UFJF, 2010.

DUNLAP, Joanna C.; GRABINGER, Scott. Preparing Students for Lifelong Learning: A Review of Instructional Features and Teaching Methodologies. Performance Improvement Quarterly, v. 16, n. 2, p. 6-25, Oct. 2008. DOI: 10.1111/j.1937-8327.2003.tb00276.x. Available from:

<http://doi.wiley.com/10.1111/j.1937-8327.2003.tb00276.x>. Visited on: 12 June 2021. 
GAEBEL, Michael et al. Digitally Enhanced Learning And Teaching. [S.I.], 2021. Available from: <https://eua.eu/downloads/publications/digi-he\%5C\%20survey\%5C\%20report.pdf >. Visited on: 1 June 2021.

GARRISON, D. R.; VAUGHAN, Norman D. Blended learning in higher education: framework, principles, and guidelines. 1st ed. San Francisco: Jossey-Bass, 2008. (The Jossey-Bass higher and adult education series).

ÍLIN, Güiden et al. Better e-Learning for Innovation in Education. Istanbul: ÖzKaracan, 2017.

KONRATH, Mary Lúcia Pedroso; TAROUCO, Liane Margarida R.; BEHAR, Patricia Alejandra.

Competências: desafios para alunos, tutores e professores da EaD. RENOTE, v. 7, n. 1, June 2009. DOI:

10.22456/1679-1916.13912. Available from: <https://seer.ufrgs.br/renote/article/view/13912>. Visited on: 28 Sept. 2019.

LI, Cathy; LALANI, Farah. The COVID-19 pandemic has changed education forever. This is how. [S.I.: s.n.], 2020. Available from: <https://www.weforum.org/agenda/2020/04/coronavirus-education-global-covid19online-digital-learning >. Visited on: 20 Apr. 2020.

MAJOR, Claire Howell. Do virtual professors dream of electric students? College faculty experiences with online distance education. Teachers College Record, v. 112, n. 8, p. 2154-2208, 2010. Available from: <https://www.tcrecord.org/LIBRARY/exec.asp?ContentID=15946>. Visited on: 1 June 2021.

MARTINHO, Domingos Santos. O Ensino Online nas Instituições de Ensino Superior Privado. As perspetivas: docente e discente e as implicações na tomada de decisão institucional. 2014. PhD thesis Instituto de Educação, Universidade de Lisboa, Lisboa. Available from:

<https://repositorio.ul.pt/bitstream/10451/11686/1/ulsd068758_td_Domingos_Martinho.pdf $>$. Visited on: 1 June 2021.

MATTAR, João; LOUREIRO, Ana; RODRIGUES, Elsa da Piedade. Editorial - Educação Online em Tempos de Pandemia: Desafios e Oportunidades para uma Escola Inclusiva. Interacções, v. 16, n. 54, p. 1-7, 2020. DOI: 10.25755/int.21999. Available from: <https://revistas.rcaap.pt/interaccoes/article/view/21999>. Visited on: 12 June 2020.

MCGILL, Tanya J.; KLOBAS, Jane E.; RENZI, Stefano. Critical success factors for the continuation of e-learning initiatives. The Internet and Higher Education, v. 22, p. 24-36, 2014. DOI:

10.1016/j.iheduc.2014.04.001. Available from:

<https://linkinghub.elsevier.com/retrieve/pii/S1096751614000190>. Visited on: 20 May 2020.

OLIVEIRA, Kaio Eduardo de Jesus; LIMA, Daniella de Jesus; PORTO, Cristiane de Magalhães. Educação não escolar, aprendizagem ubíqua e novas formas de aprender. Interfaces Científicas - Humanas e Sociais, v. 3, n. 3, p. 41-50, June 2015. DOI: 10.17564/2316-3801.2015v3n3p41-50. Available from: <https://periodicos.set.edu.br/humanas/article/view/2162>. Visited on: 1 June 2021.

PALLOF, Rena M.; PRATT, Keith. Building online learning communities: efective strategies virtual classroom. 2st ed. San Francisco: Josey-Bass, 2007.

RODRIGUES, Ana Luísa. Como integrar o ensino online nas instituições de ensino superior? Revista do Fórum da Gestão do Ensino Superior nos Países e Regiões de Língua Portuguesa (FORGES), Ilhéus, v. 2, n. 1, p. 117-145, 2015. Available from: <https://revistaforges.pt/index.php/revista/article/view/20/17>. Visited on: 1 June 2021.

SPECTOR, J. Michael (Ed.). Finding your online voice: stories told by experienced online educators. Mahwah, New Jersey: Lawrence Erlbaum Associates, 2007.

WAKE, Jo Dugstad; DYSTHE, Olga; MJELSTAD, Stig. New and changing teacher roles in higher education in a digital age. Journal of Educational Technology \& Society, v. 10, n. 1, p. 40-51, 2007. Available from: <https://www.jstor.org/stable/pdf/jeductechsoci.10.1.40.pdf>. Visited on: 1 June 2021.

ZWANEVELD, B.; BASTIAENS, T. Specifieke ict-competenties van docenten. Onderwijs/nnovatie, v. 9 , n. 4, p. 36-39, 2007. 